\title{
FOUR NEW OR LITTLE-KNOWN AUSTRALIOSOMATINI FROM NEW SOUTH WALES (DIPLOPODA, POLYDESMIDA, PARADOXOSOMATIDAE)*
}

\author{
by \\ C. A. W. JEEKEL \\ Institute of Taxonomic Zoology, University of Amsterdam. \\ P.O. Box 20125, 1000 HC Amsterdam, The Netherlands
}

\begin{abstract}
Redescription of Australiosoma clavigerum (Verhoeff, 1928) based on topotypical material. Descriptions of two new species of the genus Cladetbosoma Chamberlin, 1920: C. gladiator nov. spec., characterized particularly by a daggerlike femoral process of the gonopods, and $C$. inflatum nov. spec. in which the femoral process of the gonopods is quite strongly developed and transversely inflated. A new genus, Dicladosomella, is proposed for $D$. segmentata nov. spec.; it belongs to the group of Australiosomatini in which the telopodite of the gonopods is deeply split into two main branches, tibiotarsus and solenomerite, and is distinguished in particular by the solenomerite having a secondary branch in which the spermal channel makes a loop.
\end{abstract}

\section{RESUME}

Redescription d'Australiosoma clavigerum (Verhoeff, 1928) basée sur du matériel topotypique. Description de deux espèces nouvelles du genre Cladethosoma Chamberlin, 1920: C. gladiator nov. spec., se caractérisant surtout par le processus fémoral des gonopodes en forme de poignard, et $C$. inflatum nov. spec., où le processus fémoral des gonopodes est assez fort développé et transversalement renflé. On propose un genre nouveau, Dicladosomella, pour $D$. segmentata nov. spec.; celui-ci appartient au groupe des Australiosomatini dans lequel le télopodite des gonopodes est profondément fendu en deux branches principales, le tibiotarsus et le solénomérite, ce dernier se distinguant par la présence d'une branche secondaire dans laquelle le canal spermatique enregistre un lacet.

\section{INTRODUCTION}

The Paradoxosomatidae dealt with in this paper were received on loan from the British Museum (Natural History), London. They were collected in two widely separated areas of New South Wales: the region of Nowra and Jervis Bay, some $125 \mathrm{~km}$ from Sydney southward along the coast,

*) Millipedes from Australia, 3. and Wallangra, about $65 \mathrm{~km} \mathrm{N.N.W.} \mathrm{of} \mathrm{Inverell.}$ Although four species were represented in the material, only one, Australiosoma clavigerum (Verhoeff, 1928) was previously known, the other three being undescribed. Lying at a distance of about $260 \mathrm{~km}$ from the coast, Wallangra constitutes the farthest inland record of a New South Wales millipede to date.

The material is deposited in the B.M. (N.H.); where possible some specimens have been retained for the collection of the Zoölogisch Museum, Amsterdam.

For general information on the taxonomy and distribution of the paradoxosomatids of New South Wales the reader is referred to two previous publications (Jeekel, 1968, 1981).

\section{Genus Australiosoma Brölemann, 1913}

Australiosoma Brölemann, 1913: 89; Jeekel, 1968: 24. Rbopalowales Verhoeff, 1928: 89, 92.

R e marks. - Australiosoma is a homogeneous group of three closely related species occurring in the southern half of eastern New South Wales. The genus is characterized by the gonopods having a relatively elongate prefemur and an erect acropodite deeply split into three main branches: solenomerite, femoral process and tibiotarsus. The solenomerite has a preapical process containing a loop of the spermal channel.

The genus is obviously related to Hoplatria Verhoeff, 1941, from Victoria, which has basically the same gonopod structure, but lacks the accessory branch of the solenomerite, the spermal channel following a straight course towards the apex. 
Australiosoma furthermore appears to be quiteclosely related to Myallosoma Verhoeff, 1928, occurring in the central part of coastal New South Wales, with which it agrees in the particular structure of the solenomerite. Myallosoma is distinct, however, in having a shorter ovoid prefemur, with its axis quite oblique on the main axis of the acropodite, a widely curved acropodite, and a bifurcate tibiotarsus.

The type-species of Australiosoma, $A$. rainbowi Brölemann, 1913, from Mt. Sassafras, has the solenomerite bearing only one preapical branch. It is not known whether or not this branch contains a loop of the spermal channel, since this is not mentioned or indicated by Brölemann. However, such a condition seems quite probable, considering the all-over similarity of the gonopods with those of the other two species.

A. michaelseni (Attems, 1931), from the Blue Mountains, in its gonopods differs from $A$. rainbowi in details only. Attems has indicated the loop of the spermal channel in the accessory process of the solenomerite.

A. clavigerum (Verhoeff, 1928), redescribed here after topotypical material, is distinguished from the other two species by having a second additional branch near the apex of the solenomerite projecting distad.

To facilitate the comparison of the available gonopod drawings of the three species it should be pointed out that Brölemann designated the femoral process in $A$. rainbowi as tibial branch, and the tibiotarsus as tarsal branch, that Verhoeff used a correct designation, and that Attems called the femoral branch in A. michaelseni "Tarsalast" and the tibiotarsus "Nebenast".

\section{KEY TO THE SPECIES OF AUSTRALIOSOMA}

1a. Small species: width of male 1.5-1.7 mm. Dorsum unicolourous . . A. michaelseni (Attems, 1931)

b. Larger species: width of male 4.0 to $4.5 \mathrm{~mm}$. Dorsum dark coloured with a pair of yellowish paramedian bands . . . . . . . . . . . 2

2a. Solenomerite with one preapical process. Femoral process projecting a little distad of solenomerite . .

- . . . . A. rainbowi (Brölemann, 1913)

b. Solenomerite with two preapical processes, one of which contains a loop of the spermal channel. Femoral process not projecting distad of solenomerite

. A. clavigerum (Verhoeff, 1928)
Australiosoma clavigerum (Verhoeff, 1928)

Fig. 1.

Rhopalowales clavigera Verhoeff, 1928: 103, pl. VIII figs. 11-15.

Australiosoma clavigerum; Jeekel, 1968: 24.

M a teri a 1. - New South Wales, Nowra, V.1927, under bark (leg. Dr. F. A. Rodway), 1 ô ; Nowra, 8.VII.1933, under a $\log$ (leg. Dr. F. A. Rodway), 1 î; Nowra, VII.1927, under cake of old cowdung (leg. F. A. Rodway), 1 o, $1 \uparrow$.

Description. - Colour: Head and antennae dark brown. Lower part of the clypeus, a ring around the antennal sockets, the sutures of the lateral sclerites, the distal margins of the antennomeres and the intersegmental membranes yellowish. Tip of antennae whitish. Collum dark brown; behind the vertex of the head along the anterior margin a rather narrow yellow band, widest medially. At the posterior border a rather small median triangular yellow spot, pointing cephalad, about as wide as the anterior band. The spot a little darkened medially. In some specimens the posterior spot may be larger and is then connected by a narrow yellowish band with the middle of the anterior yellow band. A medial dark line may be more apparent in those specimens. Lateral margins of sides of collum also somewhat yellowish. Body somites dark brown, with a pair of continuous paramedian yellow bands, narrowing slightly in the waist area, and separated medially by a narrow dark stripe. Largest width of yellow band equal to half the width of the metasomites. Paranota entirely yellow. Venter, sternites and the ventral side of the proximal podomeres yellowish brown. Tarsal tips pale. Dorsal side of the proximal podomeres and the distal podomeres brown, darkest in the three distal podomeres. Anal somite dark brown, the middorsal part of the ring and the epiproct yellow. Epiproct also ventrally yellow. Paraprocts dark brown, the margins yellow. Hypoproct yellow.

Width: $\delta: 4.3-4.4 \mathrm{~mm}$, $9: 4.5 \mathrm{~mm}$.

Head and antennae: Labrum moderately deeply and rather narrowly emarginate. Clypeus moderately convex, strongly impressed towards the labrum. Lateral margins widely convex, with a rather weak notch above the labrum. Headplate rather coarsely rugulose-punctate in the clypeal area, smooth and rather shiny, or a little rugulose, 
in the frontal and vertigial regions. Pubescence moderate in the clypeus to rather sparse in the frons, vertex hairless; the lateral sclerites almost hairless. Setae of moderate length. Antennal sockets separated by 1.3 times the diameter of a socket or by 0.6 times the length of the 2nd antennomere. Bean-shaped area indistinct. Postantennal groove rather deeply and moderately widely impressed, the wall in front rather prominent. Vertex longitudinally widely and almost evenly convex, transversely flat, raised vaguely at lateral edges. Vertigial sulcus moderately impressed, running downward to the upper level of the antennal sockets, with fine transverse wrinkles. Antennae of moderate length and width, somewhat clavate, the 6th antennomere a little thicker than the others. Antennomeres subcylindrical, each widening distad, the 5th and particularly the 6th antennomere a little more obconical; the 6 th not inflated. Relative length of antennomeres 2 to $6: 1.00,1.00,0.95,0.90,0.75$. Pubescence moderate in proximal antennomeres, becoming rather dense in distal ones.

Collum: A little wider than the head, sub-

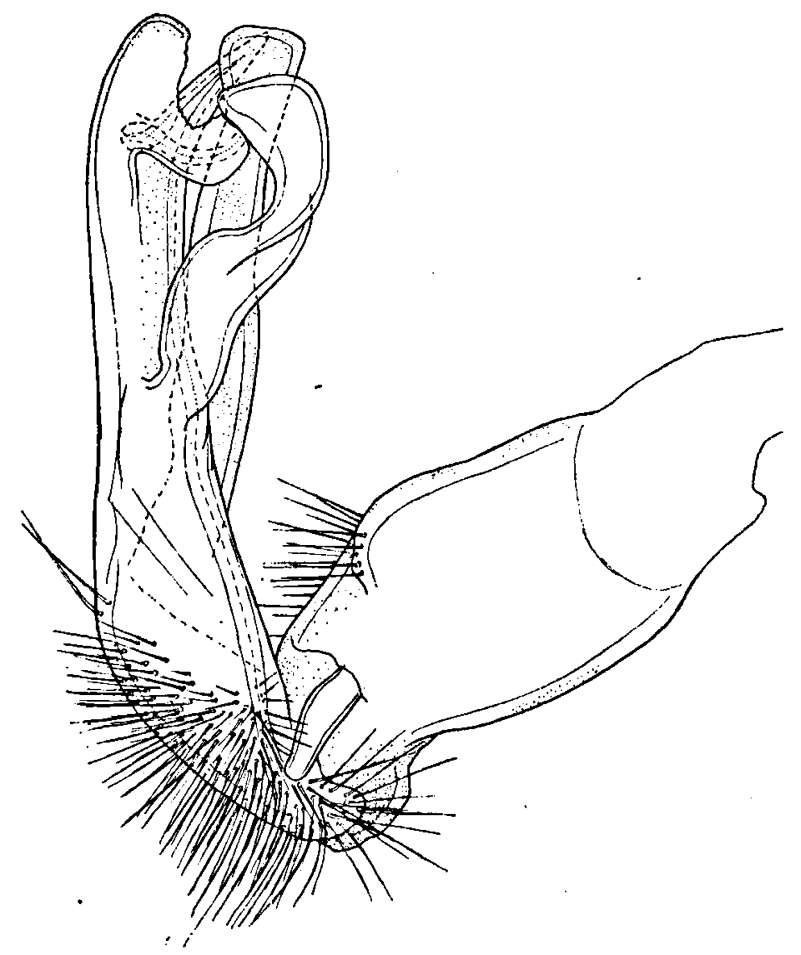

Fig. 1. Australiosoma clavigerum (Verhoeff, 1928), \& topotype, right gonopod, medial aspect. trapezoidal in dorsal outline. Anterior border straight in the middle, widely rounded more laterally, and straight again towards the sides. Posterior margin widely and weakly concave in the middle, very weakly rounded more laterally. Lateral margin rather widely and evenly rounded. Surface of collum almost smooth, shiny, hairless, longitudinally weakly convex, a little more convex near anterior margin; transversely almost flat in the middle, rather strongly convex more laterally, sides strongly sloping, but not perpendicular. Marginal rim laterally rather narrow to slightly incrassate, moderately raised, but not brimlike. The premarginal furrow fading away towards the middle of the anterior border.

Somites: Rather weakly constricted. Waist rather narrow, distinctly demarcated from prosomites, weakly from metasomites. Waist dorsally distinctly ribbed, and from about the level of the paranota downward to the level of the stigmata finely striate. Prosomites rather dull by a fine cellular structure. Metatergites rather shiny, somewhat rugulose, hairless. Transverse furrow present from the 5th to the 17th somite, rather weakly but sharply impressed, laterally disappearing at a distance from the dorsal furrow of the paranota about equal to the dorsoventral width of a poreless paranotum. Transverse furrow without apparent sculpture. Sides dullish or somewhat rugulose-granulose; in the 2 nd to 4 th somites and partly in the 5th somite with minute granulation. Pleural keels represented in the 2nd to 4th somites by weak, finely granular ridges, weakly prominent and not produced caudally. In the 5th to 7th somites only weakly defined longitudinal swellings, most distinct at posterior side of 7 th somite.

Paranota: Second somite a little wider than the collum; the 3 rd a little narrower than the 2nd, and the 4th a little narrower than the 3rd; 5 th wider than 4th. Paranota of 2nd somite with the anterior border widely convex, about transverse on the longitudinal axis. Lateroanterior edge narrowly rounded, with a vaguely developed lateral tooth. Lateral margin widely and weakly convex, slightly diverging caudad. Caudal edge about rectangular, produced and projecting a little caudad of margin of somite. Posterior margin short, straight. Paranota on a low level, just visible 
from above, sloping a little laterad. Marginal rim in lateral aspect of moderate and equal width, dorsally widely concave, anteriorly rather abruptly, posteriorly gradually curving upward. Paranota of 3 rd somite widely convex laterally, with the posterior edge acutely angular, produced and projecting as in the 2nd somite. Posterior margin short, weakly concave. Dorsal margin in lateral aspect concave, turning upward a little caudally, and curving rather abruptly dorsad anteriorly towards the waist. Ventral demarcation distinct only in the caudal half; dorsoventral width slightly larger than in the 2nd somite. Paranota of 4th somite similar to those of the 3rd, but the caudal margin very short, and the caudal edge bluntly angular, produced and projecting caudally a little less than in the 3rd somite. Dorsoventral width a little larger than in the 3 rd somite, the upper concavity a little wider. Paranota of 5 th and subsequent somites weakly developed. Poreless paranota widely convex laterally, the posterior edges a little acutely angular, scarcely produced and not projecting. Posterior border straight or a little concave, very short. Poriferous paranota a little more prominent, the lateral margin somewhat more convex, especially in the caudal half of the paranota. Posterior edges less angular, not produced and not projecting except in the 16th to 18th somites, where they are slightly projecting caudad of the margin of the somite. Posterior margins a little convex. In lateral aspect the poreless paranota are widely concave dorsally, the dorsal furrow ending anteriorly near the waist, and caudally turning upward and paralleling the caudal margin of the somite shortly. Ventral demarcation only in the caudal half of the paranota. Poriferous paranota with the upper margin anteriorly concave, posteriorly a little convex. Poriferous paranota about one and a half times wider dorsoventrally than the poreless. Ventral demarcation converging with the dorsal demarcation in an acute angle, which is somewhat wider in the poriferous paranota than in poreless ones. Pores in a small oval excavation about half way the dorsal and ventral demarcations.

Sternites and legs: Sternites of middle somites longer than wide (ratio $1.3: 1.0$ ). Cross impressions moderately developed; the longitudinal impression wide, the transverse furrowlike between the subsequent coxae. No sternal cones. Pubescence rather dense to moderate, the setae longish. Sternite of 4th somite wide, transversely widely concave; pubescence rather weak. Sternite of 5th somite with a broad subquadrate process, a little longer than wide, and almost as wide as the distance between the anterior coxae. Process directed downward and a little cephalad, but projecting scarcely in front of the sternite. Anterior surface of process rather convex, apically provided with a dense brush of short setae. Posterior surface a little concave in profile, pubescence moderate, setae longish. Behind the process a deep transverse impression. Caudal half of sternite not flattened, with a longitudinal impression. Pubescence rather dense, setae longish. Sternite of 6th somite deeply excavate, at posterior side level with the ventral side of the metasomal ring, anteriorly weakly raised. No longitudinal or transverse impressions. Coxae of legs a little more widely separated, the coxal sockets somewhat raised. Pubescence moderate, with four tufts of setae and some isolated ones. Sternite of 7 th somite with a low finely granular ridge laterocephalad of gonopod aperture. Coxae of ambulatory legs pressed a little aside. Sternite of 8th somite anteriorly flattened, weakly raised, without longitudinal impression, pubescence unapparent. Anterior coxae a little more widely separated. Transverse furrow weak. Posterior half of sternite not modified. Legs rather stout, of moderate length. Prefemur incrassate, dorsally rather strongly convex; femora not arched. Pubescence ventrally rather dense to moderate, setae longish; pubescence dorsally unapparent except on tarsi where moderately dense. Scopulae gradually thinning out in the second half of the body, absent in the last two pairs of legs. First pair of legs incrassate, with the usual ventrofemoral tubercle. Legs of 2nd pair with coxae medially rounded, not distinctly produced. Relative length of podomeres 2 to 6 in the middle of the body: $0.60,1.00$, $0.50,0.55,0.65$.

Anal somite: Dorsal profile weakly convex, a vague impression anteriorly. Epiproct rather thick, moderately long and rather wide, ventrally a little concave. Sides rather weakly and straight 
converging; without stepwise narrowing near apex. Apex truncate, scarcely emarginate, with narrowly rounded edges. Setae not on granules. Paraprocts with moderately wide and moderately high rims; the setae on vague small swellings. Hypoproct longish, parabolically rounded; setae not on granules.

Gonopods (fig. 1): Coxa robust, narrowing a little distad. Prefemur somewhat elongate; its longitudinal axis making a wide angle with the axis of the acropodite; its distal demarcation oblique. Femur abortive; femoral process rodlike, reaching about as far distad as the solenomerite, its apex truncate, slightly widened. Tibiotarsus sigmoidally curved, constricted a little halfway. Solenomerite strongly developed, with a strong spinelike process pointing distad and slightly cephalad and containing a loop of the spermal channel, and a strong, rounded additional process pointing distad. Spermal channel running along the medioanterior side of the solenomerite towards the apex which is pointing mesad and a little cephalad.

Female: Vertex transversely widely convex. $\mathrm{Cly}-$ peus only moderately impressed towards the labrum. Antennal sockets separated by 1.6 times the diameter of a socket or by 0.75 times the length of the 2 nd antennomere. Relative length of antennomeres 2 to $6: 1.00,0.90,0.95,0.85$, 0.70 . Collum transversely more evenly convex than in the male. Pleural keels not indicated from 5th somite onwards. Sternites of middle somites as long as wide. Cross impressions less impressed than in the male, pubescence almost as dense as in the male. Legs with the prefemora more elongate and less incrassate and less convex dorsally than in the male. Relative length of podomeres 2 to $6: 0.70,1.00,0.45,0.45,0.75$. Pubescence almost as dense as in the male. Epigynal structure consisting of a posterior and lateral callous expansion of the coxae, covering part of the ventral surface of the 3rd metasomite. Coxae mediodistally only slightly conically produced. Ventral side of 3 rd somite widely and weakly concave behind the coxae, with a low median triangular process pointing cephalad; the surface without sculpture.
Remarks. - Verhoeff described this species in a rather incoherent and fragmentary way, leaving many important points unnoticed, reason enough for providing a more lengthy description here. Furthermore, it is clear now that he illustrated the telopodite of the gonopod from a medial aspect.

Besides by colour, size and other morphological details, the species is particularly characterized by the distal lobe of the solenomerite. This process does not appear to have any homolog in the gonopods of other australiosomatine genera, and must be regarded as an expansion of the solenomerite sui generis, without particular significance from a comparative morphological point of view.

\section{Genus Cladethosoma Chamberlin, 1920}

Cladethosoma Chamberlin, 1920: 105; Jeekel, 1979: 649. Leucotessara Verhoeff, 1928: 90, 92; Jeekel, 1968: 24. Walestessara Verhoeff, 1937: 137.

R e marks. - This genus has four adequately characterized species: C. clarum (Chamberlin, 1920) (syn. Australiosoma verboeffi Attems, 1931), C. cruciatum (Verhoeff, 1937), C. forceps (Verhoeff, 1941), and C. lucidum (Verhoeff, 1928). Some more species appear to belong to the same group, but should be re-examined to verify their status (cf. Jeekel, 1968: 24, sub Leucotessara). Three of the species have been recorded from the central area of the New South Wales coastal region, the fourth was described from Gippsland, Victoria. They are characterized mainly by differences in the shape of the femoral process, and by minor details in size, colour, and the paranota.

With regard to the femoral process $C$. clarum, from Sydney, and C. forceps, from Gippsland, appear to be quite similar. In these two species the femoral process does not have a separate lobe a little distad of the basal constriction of the process which characterizes both $C$. cruciatum, from Comboyne, and C. lucidum, from Duggan's Gully (marked z by Verhoeff, 1937, and y by Verhoeff, 1928).

Cladethosoma appears to be related most closely to Gigantowales Verhoeff, 1937, from Comboyne, 
which is distinct in having a well-developed femoral section of the gonopods, and appears to differ in the structure of the tibiotarsal branches as well.

Hoplatessara Verhoeff, 1928, ranging from the Blue Mountains area in New South Wales to Gippsland, Victoria, has gonopods which superficially are quite similar to those of Cladethosoma. But the differences which have been pointed out earlier (Jeekel, 1968) seem quite important, and the overall similarity in the gonopods of the two genera might be a result of evolutionary convergence.

The two species presently described add to the spectrum of diversity in the shape of the femoral process of the gonopods in Cladethosoma. C. gladiator nov. spec. stands out in having the process styliform instead of broadly laminate. $C$. inflatum nov. spec. approaches $C$. clarum and $C$. forceps in the outline of the process, but the process is strongly inflated instead of laminate. Moreover, $C$. inflatum is characterized by the gonopods having a distinct femoral section, whereas in all other species of Cladetbosoma this section is strongly reduced.

For the sake of comparison of the present descriptions with those of previous authors the names used for indicating the femoral process and the tibiotarsus in the past are given in table I.

\section{KEY TO THE SPECIES OF CLADETHOSOMA}

1a. Femoral process rodlike, distally acuminate. Metatergites dorsally brown, with the caudal half yellowish. Width of male $3.4 \mathrm{~mm}$. . . C. gladiator nov. spec.

b. Femoral process transversely flattened, laminate or inflated, its apex more or less recurved, uncate. Colour pattem different. Usually larger species . . . 2

2a. Femoral process bearing a serrulate or rounded lobe near its base. . . . . . . . . 3

b. Femoral process without lobe near the base 4 3a. Preapical triangular process of femoral process wide, simple. Basal lobe of femoral process rounded . . . C. Iucidum (Verhoeff, 1928)

b. Preapical process of femoral process finely denticulate. Basal lobe of femoral process distally not rounded, but with an undulate margin

- . . . . . C. cruciatum (Verhoeff, 1937)

4a. Femoral process strongly inflated. Tibiotarsal branches arising relatively distant from the apex of the prefemur, resulting in a distinct femoral section of the acropodite . . . . . . . . C. inflatum nov. spec.

b. Femoral process laminate, not inflated. Femoral section of acropodite shorter, tibiotarsal branches arising close to the apex of the prefemur . . . . . S

5a. Dorsum of metatergites dark with two parallel-sided paramedian yellowish bands, separated by a narrow dark line. Preapical process of femoral process narrow, acutely angular . . . C. clarum (Chamberlin, 1920)

b. Metatergites dorsally with a pair of yellow bands, diverging caudad, enclosing a brown triangular spot pointing cephalad. Preapical process of femoral process widely triangular. . C. forceps (Verhoeff, 1941)

\section{Cladethosoma inflatum nov. spec.}

Figs. 2-3.

M a teri a l. - New South Wales, Jervis Bay, under a $\log$, II.1925 (coll. F. A. Rodway), ô holotype.

Desciption. - Colour: The specimen is probably discoloured. Head pale castaneous, labral area yellowish. Antennae pale castaneous in the distal antennomeres, paler in the proximal ones. Collum of same general colour as the head, with a rather broad yellowish median band which is constricted halfway. Metatergites pale castaneous with a pair of yellowish paramedian bands diverging caudad and enclosing a dark triangle pointing cephalad. Prosomites also with two paramedian bands, which are medially separated by a fine dark line. Paranota yellowish. Anal somite dorsally yellowish. Sides and venter of body somites and the legs yellowish brown.

Width: $4.6 \mathrm{~mm}$.

TABLB I

\begin{tabular}{lcc}
\hline & femoral process & tibiotarsus \\
\hline clarum (Chamberlin, 1920) & tibial branch & tarsal branch \\
verhoeffi Attems, 1931 ** & "Tarsalast" & "Nebenäste der Tibia" \\
cruciatum (Verhoeff, 1937) & "Tibiotarsus" & "postfemorale Fortsätze" \\
forceps (Verhoeff, 1941) & "Tibiotarsus" & "Parsolänomerite" \\
lucidum (Verhoeff, 1928) & tibiotarsus & femoral lateral rami \\
\hline
\end{tabular}

**. - C. clarum (Chamberlin, 1920). 
Head and antennae: Labrum weakly and narrowly emarginate. Clypeus weakly convex, weakly impressed towards the labrum. Its lateral border widely rounded, with a distinct notch just above the labrum. Headplate moderately densely punctate in the clypeal area, and with fine wrinkles along the vertigial sulcus and on the lateral parts of the vertex. Antennal sockets separated by 1.6 times the diameter of a socket or by 0.6 times the length of the 2nd antennomere. Postantennal bean-shaped area obsolete. Postantennal groove very deep and wide, the wall in front strongly inflated. Frontal area of head with a pair of paramedian ridges running from the lower part of the vertex downward and fading away in the middle of the clypeus, and separated by a wide and deep median furrow. Pubescence moderately dense in clypeus to sparse in frontal region; the setae of moderate length. Lateral sclerites of head almost hairless. Vertex transversely slightly convex in the middle, with laterally on each side a distinctly inflated prominence. Vertex in profile almost flat, abruptly rounded towards the frons. Vertigial sulcus moderately impressed, growing deeper towards the frons and passing over into the median frontal furrow. Antennae rather long and slender. The antennomeres cylindrical, widening very little distad, the 6th more obconical. Pubescence moderate in the proximal antennomeres, becoming rather dense in the distal ones. Antennae hardly clavate, with the 6th antennomere only a little thicker than the more proximal ones. Relative length of antennomeres 2 to 6: 0.95, 1.00, 1.00, $1.00,0.80$.

Collum: A little wider than the head, trapezoidal in dorsal outline. Anterior margin widely emarginate, widely convex more laterally, and weakly convex towards the lateral sides. Posterior margin widely and weakly emarginate in the middle, laterally faintly rounded. Lateral sides somewhat asymmetrically and rather widely rounded, only a little more narrowly rounded at posterior side. Surface of collum weakly coriaceous, longitudinally weakly and almost evenly convex, transversely a little concave in the middle, rather strongly convex more laterally, the sides strongly sloping. Lateral marginal rim a little flaring, brimlike and not incrassate. Premarginal furrow almost disappearing towards the middle of the anterior border.

Body somites: Prosomites somewhat dulled by a fine cellular structure. Constriction moderate, the waist rather narrow, dorsally distinctly striate, more laterally finely striate down to about the middle of the sides. Metatergites rather shiny, weakly coriaceous, with fine undulated sulci. Transverse furrow weakly but rather sharply impressed, without distinct sculpture but with some very fine longitudinal wrinkles. Furrow present from the 5 th to the 17 th somite, weakly indicated on the 4th somite, disappearing laterally at a distance from the dorsal delimitation of the paranota equal to the dorsoventral width of a poriferous paranotum. Sides dullish, subgranulose, not granular in anterior somites. Pleural keels represented by low, weakly defined ridges in the 2nd to 4 th somites, and indicated by scarcely prominent longitudinal bulges in the 5 th to 7 th somites.

Paranota: Second somite distinctly wider than the collum, width of $3 \mathrm{rd}$ and 4th somites subequal, scarcely narrower than the 2 nd; 5 th somite a little wider than the 4th. Paranota of 2nd somite with the anterior border widely convex, a little thrust forward. Lateroanterior edge rather widely rounded, with an abortive lateral tooth. Lateral border weakly convex, converging a little. caudad. Caudal border short, rather narrowly rounded, the edge scarcely produced caudad. In lateral aspect the paranota are situated on a rather low level. The upper margin is widely concave, turning more strongly upwards anteriorly and posteriorly. Marginal rim narrow. Paranota of $3 \mathrm{rd}$ somite in dorsal aspect almost semicircularly rounded. The margin dorsoventrally rather narrow, ventrally not sharply demarcated. Paranota of 4 th somite similar to those of the $3 \mathrm{rd}$, but laterally more widely rounded, and dorsoventrally a little wider. Paranota of Sth and subsequent somites weakly developed. In dorsal aspect faintly convex, diverging a little caudad, and caudally rather widely rounded, disappearing at a little distance from the posterior margin of the somite. No distinct caudal edge or posterior border. Only in the 18th somite there is a slightly angular posterior edge. In lateral aspect the poreless paranota 
are weakly concave dorsally, the poriferous faintly convex. The marginal furrow turns dorsad anteriorly and disappears well before reaching the waist; posteriorly it turns upward and parallels the caudal margin of the somite over a little distance. Ventral demarcation distinct only in the caudal half of the paranota, meeting the upper furrow at an acute angle. Dorsoventral width of poriferous paranota about twice that of poreless paranota.

Sternites and legs: Sternites of middle somites about as long as wide. Cross impressions rather weakly developed; the longitudinal impression wide, the transverse impression furrowlike only between the coxal sockets. No sternal cones. Pubescence rather dense, with setae of moderate length. Sternite of 4 th somite wide, rather widely concave; pubescence moderate. Sternite of 5th somite with a parabolic to pentagonal process between the anterior coxae, about as long as wide, bluntly angular medially, a little narrower than the distance between the coxae. Process directed downward and a little cephalad, but scarcely projecting in front of the sternite; its anterior surface a little convex, and posterior surface a little concave. Anterior side apically with a brush of short setae. Posterior surface moderately setiferous, the setae longish. Behind the process no distinct transverse furrow, but a weak impression. The surface of the caudal half of the sternite sloping, with a slight median impression. Pubescence moderately dense, with longish setae. Sternite of 6th somite with the coxal sockets of both pairs of legs somewhat pressed aside. Surface level with the ventral side of the metasomal ring, the coxal sockets raised only a little. No cross impression, but the area between the posterior coxae slightly impressed. Pubescence moderately dense, with longish setae. Sternite of 7 th somite without calluses in front of the gonopod aperture; the coxae of the ambulatory legs pressed a little aside. Sternite of 8th somite scarcely modified; only the cross impression weaker. Legs rather long, moderately slender, the prefemora not particularly convex dorsally; femora scarcely arched. Pubescence of all podomeres ventrally dense to rather dense; the coxae and prefemora of the anterior legs with a dense brush of rather short setae, setae otherwise of moderate length. Pubescence on dorsal side of podomeres unapparent; only tibiae and tarsi moderately pubescent dorsally. Scopulae of distal podomeres present in most legs, thinning out in the legs of the posterior half of the body, and absent in the last two pairs. Legs of the first pair with a ventral femoral tubercle. Coxae of 2nd pair medially slightly conically produced. Relative length of podomeres 2 to 6 in the middle part of the body: $0.60,1.00,0.70,0.70,0.75$.

Anal somite: Dorsal profile weakly convex. Sides of epiproct faintly concave, rather strongly converging. Epiproct of moderate length, moderately thick and moderately wide; the ventral side weakly concave. Apex truncate and weakly emarginate. No stepwise narrowing of epiproct towards the apex; the setae not on tubercles. Paraprocts with marginal rims rather low and of moderate width. Setae on abortive tubercles. Hypoproct broadly triangular, with the sides weakly concave, and the apex narrowly truncate, faintly convex. Setae not on tubercles.

Gonopods (figs. 2-3): In profile characterized by a slender and somewhat elongate basal section of the acropodite, apparently the reduced but not completely disappeared femorite. Femoral process quite voluminous distad of the basal constriction: broadly transversely expanded and inflated. Its apex acuminate and curving mesad; on the medial side a preapical triangular process pointing distad and mesad a little. Solenomerite broadly expanded about halfway its length. Tibiotarsus arising well proximally of the separation between solenomerite and femoral process, rather short, somewhat widened at base and soon dividing into two lanceolate prongs of which the medial one is slightly longer than the lateral one. The lateral tibiotarsal prong widening a little distally and apically obliquely truncate and slightly serrulate.

$\mathrm{R} \mathrm{e} \mathrm{m} \mathrm{a} \mathrm{r} \mathrm{k} \mathrm{s.} \mathrm{-} \mathrm{According} \mathrm{to} \mathrm{the} \mathrm{structure} \mathrm{of} \mathrm{the}$ femoral process of the gonopods this new species approaches $C$. clarum (Chamberlin) and $C$. forceps (Verhoeff). However, in these two species the apex of the process is more distinctly acuminate and more uncate being slightly recurved. Moreover, the emargination between the apex and the 

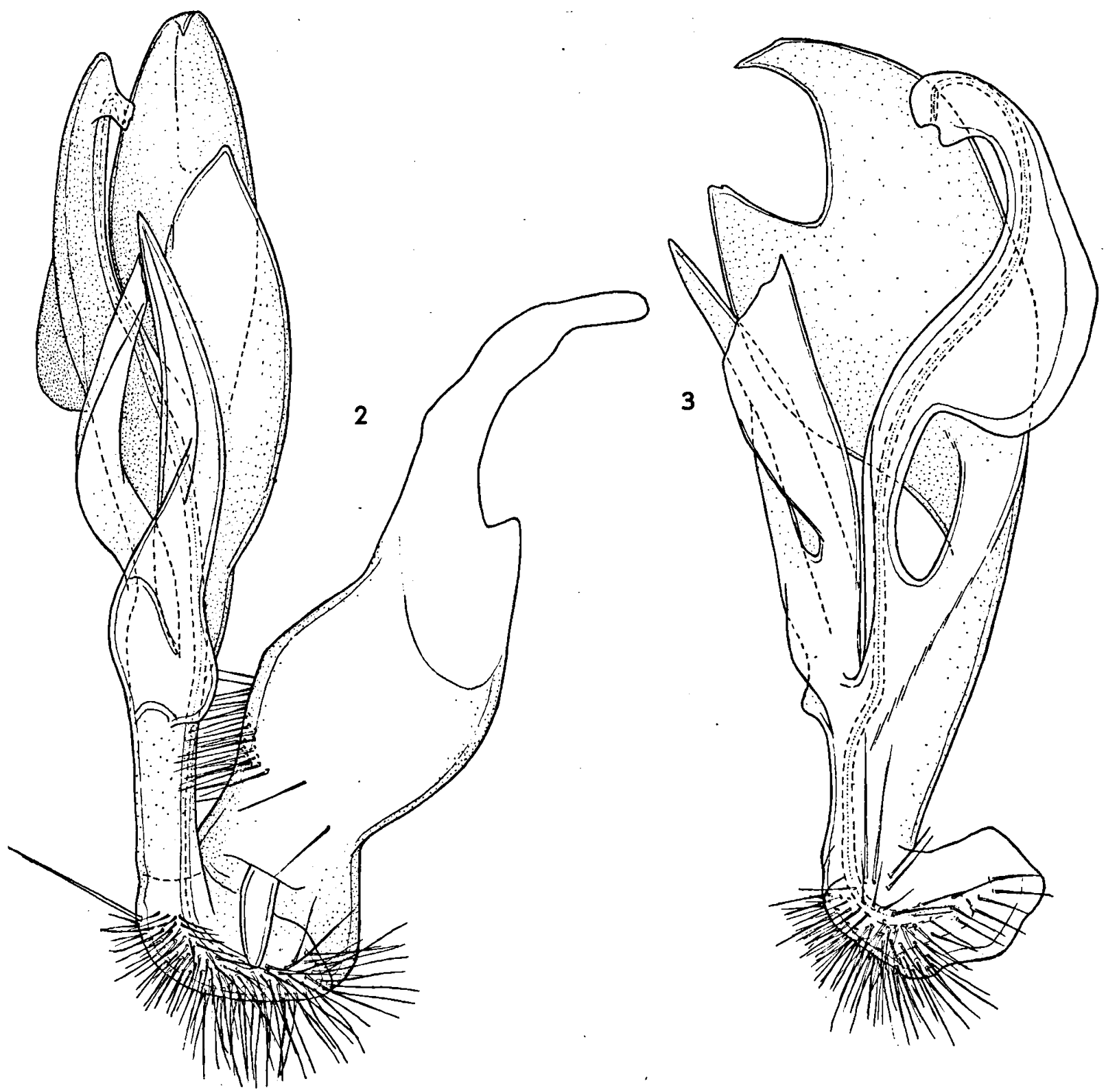

Figs. 2-3. Cladethosoma inflatum nov. spec., of holotype: 2, right gonopod, medial aspect; 3, telopodite of left gonopod, caudal aspect.

preapical triangular process is large and wide in C. inflatum, being narrow in the two other species. C. inflatum can be distinguished from all other species of Cladethosoma by the elongate femoral section of the acropodite of the gonopods, reminding somewhat of the condition in the genus Gigantowales Verhoeff, 1937. Furthermore the large inflated femoral process is quite characteristic.
The particular structure of the headplate of the male described for $C$. inflatum seems to be present also in $C$. cruciatum (Verhoeff), and perhaps, though apparently less pronounced, in $C$. clarum and $C$. lucidum (Verhoeff) as well. The wide emargination of the frontal margin of the collum reminds strongly of the condition described for the female (not the male!) of Streptocladosoma dissimile Jeekel (cf. Jeekel, 1980: 5, fig. 7) from 
northern Queensland. Unfortunately, it is not yet known if this particular structure occurs also in the females of Cladethosoma.

\section{Cladethosoma gladiator nov. spec.}

Figs. 4-6.

Materia I. - New South Wales, Wallangra, IX.1929 (leg. F. A. Rodway), ô holotype.

Description. - Colour: Head castaneous, the labral area paler; a ring around the antennal sockets yellow. Antennae castaneous, the apex of each antennomere and the intersegmental membranes yellowish; antennal tip whitish. Collum castaneous, with a narrow yellow band along the anterior margin behind the vertex of the head, and a broader transverse yellow band, widest medially, along the posterior margin. Somites castaneous, the posterior half of the metasomites, also below the paranota, yellow. Paranota entirely castaneous. Venter and sternites pale castaneous, the legs castaneous with their ventral side paler. Anal somite castaneous with a yellow epiproct; the yellow colour of the epiproct extends in a triangle on the dorsal surface of the anal ring proper. Paraprocts with yellowish margins. Hypoproct pale brownish.

Width: $3.4 \mathrm{~mm}$.

Head and antennae: Labral emargination rather shallow and of moderate width. Clypeus moderately convex, very strongly impressed towards the labrum. Lateral margin faintly rounded, with a weak notch above the labrum. Headplate coarsely punctate in the clypeal area, otherwise with some irregular wrinkles. Pubescence moderate in the clypeus to rather sparse in the frontal region; lateral sclerites of head almost hairless; vertex hairless. Setae of moderate length. Antennal sockets separated by 1.2 times the diameter of a socket or by 0.6 times the length of the 2 nd antennomere. Postantennal bean-shaped area obsolete. Postantennal groove rather wide and deep; the wall in front rather prominent. Vertex widely and evenly convex longitudinally, almost flat transversely, but without lateral prominences. Vertigial sulcus rather weakly impressed, disappearing above the upper level of the antennal sockets. Antennae of moderate length and width, rather distinctly clavate, with 5th and 6th antennomeres thickest. Antennomeres subcylindrical, each widening distad; the 6th more obconical, scarcely inflated. Pubescence moderate in the proximal antennomeres to dense in the distal ones. Relative length of antennomeres 2 to 6: 1.00 , $1.00,0.90,0.85,0.75$.

Collum: A little wider than the head, subtrapezoidal in dorsal outline. Anterior border straight or faintly convex in the middle, widely rounded more laterally, and straight towards the lateral sides. Posterior border widely and weakly emarginate, laterally faintly convex. Lateral sides widely and asymmetrically rounded, more strongly rounded anteriorly. Surface of collum rather shiny, smooth, hairless, longitudinally widely and evenly convex, transversely weakly convex in the middle, more strongly convex towards the sides; the sides almost perpendicular. Marginal rim laterally distinctly incrassate, a little callous, not brimlike. The premarginal furrow fading away towards the middle of the anterior border.

Body somites: Rather weakly constricted by a rather narrow waist, which is distinctly demarcated from the prosomites. Waist dorsally distinctly beaded down to halfway the sides. Prosomites dullish by a fine cellular structure. Metatergites rather shiny, smooth or faintly rugulose, hairless. Transverse furrow present from the 5th to the 17th somite, indicated also in the 4th and 18 th somites. Furrow smooth or with fine striae, moderately deeply, but sharply impressed, remaining separate from the dorsal delimitation of the paranota by a distance about equal to the dorsoventral width of a poriferous paranotum. Sides smooth or with some faint wrinkles, not granular. The pleural keels obsolete, faintly indicated in the 3rd somite only.

Paranota (fig. 4): Second somite a little wider than the collum; the 3 rd a little wider than the 2nd and about as wide as the 4th; the 5th wider than the 4th. Paranota of 2nd somite with the anterior border widely rounded, a little thrust forward. Lateroanterior edge angular, a weak tooth directed downward. Lateral border weakly convex, a little more convex caudally. Caudal margin rather short, emarginate. Lateroposterior edge angular, produced caudally and projecting a little caudad 


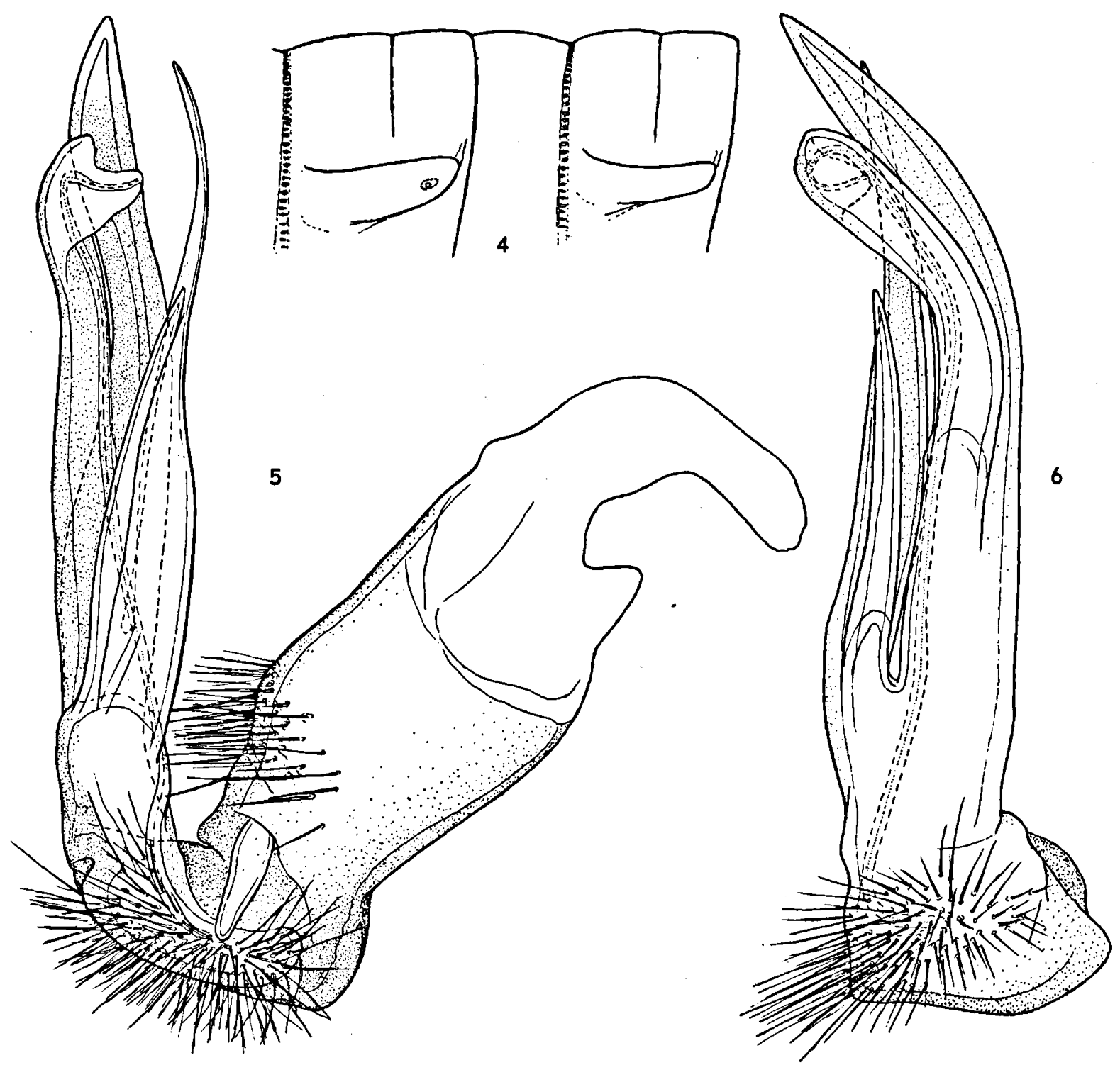

Figs. 4-6. Cladethosoma gladiator nov. spec., $\delta$ holotype: 4, left side of 10 th and 11 th somites, lateral aspect; 5 , right gonopod, medial aspect; 6 , telopodite of left gonopod, caudal aspect.

of the margin of the somite. Paranota on a low level and scarcely visible from above; the lateral margin scarcely diverging caudad. Paranota in lateral aspect with dorsal margin about straight; the marginal rim rather thick, callous. Ventral demarcation distinct, almost parallel to the dorsal margin. Posterior edge in lateral aspect rounded. Paranota of 3rd somite in dorsal aspect with the lateral margin widely and evenly rounded; posterior margin short and straight; the lateroposterior edge widely angular and scarcely produced, not projecting behind the margin of the somite. Dorsoventral width about one and a half times that of the paranota of the preceding somite. Caudal half of paranota ventrally demarcated by a depression. Upper margin faintly concave, curving upward anteriorly and posteriorly. Paranota of 4th somite similar to those of the 3rd. Lateral margin anteriorly and posteriorly more strongly rounded, the caudal edge narrowly rounded, faintly produced 
and not projecting. Dorsoventral width equal to that in preceding somite. Paranota of 5th and subsequent somites rather weakly prominent. Border anteriorly moderately, laterally widely rounded. Caudal edge narrowly rounded in poriferous somites, subangular in poreless somites. Posterior margin short, emarginate in poreless, convex in poriferous somites. Caudal edge scarcely produced in the anterior half of the body, gradually more so in the second half of the body, projecting a little behind the margin of the somite in the 15th to 19 th somites and particularly in the 18th. Dorsal margin in lateral aspect faintly concave in poreless, and about straight in poriferous somites. The upper furrow curving nearly to the waist anteriorly and turning upward caudally, shortly paralleling the posterior margin of the somite. Ventral demarcation present in about three quarters of the length of the paranota. Dorsoventral width in poriferous somites about one and a half times that of poreless somites. Ventral demarcation turning upward caudally rather abruptly, giving the poreless paranota in particular a truncate lateral aspect. Pores in an oval excavation a little below the middle of the callus.

Sternites and legs: Sternites of middle somites a little longer than wide (ratio $1.1: 1.0$ ). Cross impressions rather well developed, the longitudinat impression wide, the transverse also wide, becoming furrowlike between the subsequent coxae. No sternal cones, but in a number of somites of the posterior half of the body the coxal sockets are mediocaudally slightly inflated. Pubescence rather dense to moderate, the setae of moderate length to longish. Sternite of 4 th somite rather wide, transversely concave; pubescence rather weak. Sternite of Sth somite with a pentagonal process between the anterior coxae, which is as wide as the distance between the coxae, somewhat wider than long and having a wide apical angle. Anterior side in profile faintly convex, the process directed downward and a little cephalad, but not projecting in front of the sternite. Anterior side apically with a rather dense brush of short setae. Posterior side widely concave, rather sparsely setiferous, the setae rather long. Transverse furrow of sternite distinct. Posterior half scarcely concave, without longitudinal furrow, rather densely set with longish setae. Sternite of 6th somite deeply excavated, only anteriorly faintly raised above the ventral level of the metasomal ring. No cross impressions, only a faint transverse impression. Coxal sockets weakly raised, somewhat more widely separated than in the postgonopodial sternites. Pubescence moderate, with longish setae. Sternite of 7 th somite with a low transverse, finely granular ridge on each side in front of the gonopod aperture. Ambulatory legs pressed aside a little. Sternite of 8th somite flattened between the anterior legs, but not excavated. Anterior coxae scarcely raised, somewhat pressed aside. Posterior half of sternite almost unmodified, but the transverse and longitudinal impressions wider; pubescence moderate, with moderately long setae. Legs of moderate length, rather stout. Prefemur incrassate, dorsally rather convex. Femur faintly arched. Ventral pubescence rather dense in all podomeres, setae of moderate length to longish. Dorsal pubescence apparent only in the distal podomeres, mainly in the tarsi. Scopulae dense, thinning out near the posterior end of the body, but present up to the last leg. Relative length of podomeres 2 to 6 in middle part of the body: $0.65,1.00,0.65,0.60$, 0.65 . First leg with a well-developed ventrofemoral tubercle. Second leg with the coxa medially broadly rounded, scarcely produced. Coxae of legs of 6th somite faintly subconically produced on medial side.

Anal somite: Dorsal profile almost evenly faintly convex. Epiproct of moderate length, moderately thick, broad at base with the sides rather strongly, almost straight converging; near the apex a slight indication of a stepwise narrowing. Apex rather narrowly truncate, scarcely emarginate. Ventral side of epiproct faintly concave. Setae not on tubercles. Paraprocts with marginal rims of moderate width, rather low. Setae on faint swellings. Hypoproct subtriangular, parabolically rounded, rather broad, the sides almost straight. Setae not on tubercles.

Gonopods (figs. 5-6): Femoral section very short. Femoral process a slender lanceolate prong, projecting a little distad of the apices of the solenomerite and the tibiotarsus. Solenomerite not expanded halfway; the division between 
femoral process and solenomerite situated distinctly distad of the base of the tibiotarsal prongs. Spermal channel running along the anterior side of the solenomerite. Tibiotarsus consisting of two lanceolate prongs, of which the medial one is about one and a half times longer than the lateral one, and projects a little distad of the apex of the solenomerite.

R e m a rks. - This species is characterized in particular by the shape of the femoral process of the gonopods, the lack of a lamellate expansion of the solenomerite and the relative length of the tibiotarsus.

With regard to the shape of the femoral process a similarity with the gonopods of Gigantowales Verhoeff, 1937, should be noted. In essence, the type-species of this genus, $C$. chisholmi Verhoeff, 1937, from Comboyne, differs only in the remarkably strong development of the femoral section of the gonopods, in relation to the distal elements, and in the apparently somewhat different structure of the tibiotarsal branches. Perhaps C. gladiator deserves a separate subgeneric or generic status, but it seems better for the time being to associate it with its closest relatives which, without any doubt, are found in the genus Cladethosoma.

\section{Genus Dicladosomella nov.}

D i a $\mathrm{g}$ n os is. - Rather small-sized Australiosomatini with 20 somites and a normal pore formula. Vertex of head globose, without lateral swellings in the male. Antennae rather short, clavate.

Somites rather weakly constricted; the waist rather narrow, dorsally beaded. Metatergites smooth, hairless. Transverse furrow present from the 5th somite onwards, well impressed. Pleural keels distinct up to the 4th somite, weakly indicated on a few subsequent somites.

Paranota rather weakly developed.

Sternite of middle somites longer than wide $(\delta)$ or as long as wide ( $q$ ). Cross impressions in male rather well developed. Sternite of 5 th somite of male with a broad rounded process between the anterior coxae. Legs of moderate length.
The first pair of the male with a ventral femoral tubercle. Tibial and tarsal scopulae present in the legs of the anterior half of the body of the male.

Gonopods with the coxa relatively short. Prefemur ovoid, short; its longitudinal axis almost transverse on the axis of the acropodite. Femorite strongly reduced; no femoral process. Tibiotarsus large, laminate, arising from the mediocaudal side of the femorite. Solenomerite long, rather slender, bearing at about two thirds of its length a secondary, triangular process containing a loop of the spermal channel. Distal section of solenomerite making a wide curve in medioanterior direction. Spermal channel running along the mediocaudal side of the solenomerite, distad of the secondary process along the anterior side.

Ty pe-s pecies. - Dicladosomella segmentata nov. spec.

Remarks. - This new genus belongs to a group of Australiosomatini in which the acropodite is deeply split into two main branches: solenomerite and tibiotarsus. This group includes Dicladosoma Brölemann, 1913, with a single species recorded from the Mt. Kosciusko area, and Pbyllocladosoma Jeekel, 1968, with three known species and a subspecies, occurring in the northern half of the coastal region of New South Wales and the adjacent area of southern Queensland. Dicladosoma is characterized by a tibiotarsus which is twisted around the base of the solenomerite, so that its main body is situated cephalad, instead of caudad, of the solenomerite. In Phyllocladosoma the main body of the tibiotarsus is situated caudad of the solenomerite, and this is also the case in Dicladosomella. The solenomerite of Pbyllocladosoma is a little shorter than the tibiotarsus, and it bears a small triangular lobe just before the apex containing a loop of the spermal channel. In Dicladosomella the solenomerite is much longer than the tibiotarsus, and the secondary process containing the loop of the spermal channel is larger and situated quite distant from the apex of the solenomerite.

It seems highly probable that Dicladosomella is related most closely to Pbyllocladosoma, and that the structure of the solenomerite in the first 
genus was acquired by an evolutionary process involving the elongation of the part of the solenomerite distad of the secondary process far beyond the apex of the tibiotarsus.

The presence of a loop in the spermal channel is a peculiar feature which occurs only in the paradoxosomatid subfamily Australiosomatinae, and more specifically only in the genera Australiosoma, Myallosoma, Hoplatessara, Somethus Chamberlin, 1920, Australodesmus Chamberlin, 1920, Phyllocladosoma and Dicladosomella. Although one would tend to regard this condition as homologous in all these genera, it seems rather dubious if this is really the case. In fact. Australodesmus, on account of its general gonopod structure was referred to the tribe Antichiropodini, and there is little evidence in the structure of the gonopods of the other genera supporting the homology of the accessory process in general. Only in the case of Australiosoma and Myallosoma, and of Phyllocladosoma and Dicladosomella such a homology seems likely, but there seems to be no reason to associate these two pairs of genera with each other, nor with any of the others. On the contrary, Australiosoma is clearly closely related to Hoplatria in which a loop of the spermal channel is completely lacking. The phylogenetic status of this particular feature, therefore, remains a problem.

\section{Dicladosomella segmentata nov. spec.}

Figs. 7-9.

Materia l. - New South Wales, Nowra (leg. Dr. F. A. Rodway), $\hat{o}$ holotype, $1 \hat{s}$ and 1 i paratypes.

Des c ription. - Colour: Head and antennae dark castaneous, darkest in the frontal region, with the labral area, a narrow ring around the antennal sockets, the sutures between the lateral sclerites, the distal margins and intersegmental membranes of the five proximal antennomeres yellowish. Tip of antennae whitish. Collum also dark castaneous; the anterior margin with a narrow yellowish band, the posterior margin with a less narrow yellowish band, widest in the middle and tapering towards the lateral sides. Margin of lateral side pale brownish. Somites dark castaneous; the metatergites with a transverse yellow band along the caudal margin which reaches the transverse furrow in the middle, but narrows laterally and disappears before reaching the paranota. Posterior half of paranota also yellowish. Venter, sternites and ventral side of the three proximal podomeres yellowish; remaining portion of legs castaneous, gradually darkening towards the distal podomeres. Tip of tarsi whitish. Anal somite with the epiproct dorsally and ventrally yellow; otherwise dark castaneous. Paraprocts castaneous with pale margins; hypoproct pale brownish.

Width: ô: $2.4-2.5 \mathrm{~mm}$; ?: $2.8 \mathrm{~mm}$.

Head and antennae: Labrum moderately deeply, and rather widely emarginate. Clypeus rather well impressed towards the labrum; its lateral margin faintly convex or straight, with a distinct notch near the labrum. Headplate moderately shiny; the clypeus moderately pubescent and rather coarsely uneven by the presence of setiferous pits. Frons dispersedly setose; lateral sclerites of head weakly to scarcely pubescent. Antennal sockets separated by 1.3 times the diameter of a socket or by 0.6 times the length of the 2nd antennomere. Postantennal bean-shaped area narrow, almost obsolete. Postantennal groove moderately deep, rather wide; the wall in front moderately prominent. Vertex hairless; transversely faintly convex, almost flat, laterally more strongly rounded, but without lateral swellings; longitudinally moderately and evenly convex, not demarcated from the frontal area. Vertigial sulcus weakly impressed anteriorly and posteriorly, somewhat more impressed halfway, reaching downward to the upper level of the antennal sockets. The sulcus has a number of fine transverse wrinkles. Behind the antennal sockets the lateral parts of the vertex are also wrinkled. Antennae rather short and rather thick, distinctly clavate. The 2 nd to 4 th antennomeres subcylindrical, each widening distad; 5th antennomere more obconical in shape; the 6th obconical with the sides faintly inflated. Pubescence moderate in the proximal antennomeres, becoming rather dense in the distal ones. Relative length of antennomeres 2 to $6: 1.00,0.95,0.90,0.90,0.80$.

Collum: About of same width as the head, subtrapezoidal in dorsal outline. Anterior margin weakly convex in the middle, a little more convex 
more laterally and straight towards the sides. Posterior margin widely emarginate, laterally widely rounded, with a weak but distinct notch above the lateral rounding. Lateral sides rather narrowly and evenly rounded. Surface shining with some undulated weak wrinkles especially towards the sides, hairless. In the middle a faint median furrow. Surface transversely almost flat in the middle, laterally rather strongly rounded, with the sides almost perpendicular. Surface longitudinally weakly and evenly convex. Lateral margin with a narrow, weakly raised rim; the premarginal furrow disappearing gradually towards the middle of the anterior border.

Body somites: Constriction rather weak; the waist rather narrow, sharply demarcated from the prosomites, dorsally and dorsolaterally distinctly beaded, laterally faintly striate. Prosomites dulled by a rather pronounced minute cellular structure. Metatergites shiny, with some weak undulated rugulae. From the 5 th to the 17 th somite a rather deeply impressed transverse furrow, faintly indicated also on the 18th somite. The furrow has a fine sculpture caused by minute longitudinal striae; it disappears laterally at a distance from the dorsal delimitation of the paranota equal to about the diameter of a poreless paranotum. Sides granulose-rugulose, granulose especially in anterior somites. Pleural keels present up to the 4th somite as low curved (concavity upwards) and somewhat crenulate ridges. In the 5 th somite there is a weak swelling above the posterior legs, which diminishes in subsequent somites, being absent from the 8th onwards.

Paranota (figs. 7-8): 2nd and 3rd somite scarcely wider than the collum; 4th and 5th somites each a little wider than the preceding ones. Paranota of 2nd somite on a low level, but visible from above. Anterior margin rather widely rounded, almost transverse on the axis of the body. Lateroanterior edge narrowly rounded, subangular, with a weak lateral tooth. Lateral border faintly convex, quite weakly diverging caudad. Posterior edge acutely angular, produced caudad and projecting distinctly behind the margin of the somite. Posterior margin rather short, straight, concave at its base. The paranota are slightly sloping laterad. In lateral aspect the marginal rim is of moderate, subequal width; the dorsal and ventral demarcations straight. Premarginal furrow turning anteriorly and posteriorly abruptly upward, paralleling caudally the posterior margin of the somite shortly. Paranota of 3rd somite in dorsal aspect widely and evenly convex. Posterior edge acutely angular, produced caudad but scarcely projecting behind the margin of the somite. Posterior border short, about straight. In lateral aspect the dorsal demarcation of the paranota is about straight, curving abruptly upward at both ends, anteriorly towards the waist, and posteriorly to run shortly parallel to the posterior margin of the somite. Ventral demarcation of paranota distinct only in posterior half, the dorsoventral width rather narrow. Paranota of 4th somite similar to those of the 3rd. Posterior edge angular, produced but not projecting. Upper demarcation in lateral aspect faintly concave. Ventral demarcation only in the posterior third; dorsoventral width slightly larger than in the 3rd somite. Paranota of 5th and subsequent somites rather weakly developed. Lateral margin faintly convex, weakly diverging caudad, a little more convex anteriorly and before the caudal edge. Caudal edge acutely angular, distinctly produced, but projecting only in the 14th to 18th somites. Posterior margin rather short, straight or a little concave. Poriferous paranota a little more prominent and laterally slightly more convex. In lateral aspect the poriferous paranota are dorsally widely convex, the poreless ones faintly concave. Dorsal furrow not reaching the waist, caudally briefly paralleling the posterior margin of the somites. Ventral demarcation present in about one third of the length of the paranota, almost straight converging with the upper margin and meeting it in an acute angle. Poriferous paranota about one and a half times wider dorsoventrally than the poreless ones. Pores situated in an elongate ovoid excavation, a little below the middle of the marginal callus.

Sternites and legs: Sternites of middle somites longer than wide (ratio $1.00: 1.35$ ). Cross impressions well developed, the longitudinal impression moderately wide; the transverse impression more furrowlike, especially between the subsequent coxae. No sternal cones. Pubescence 

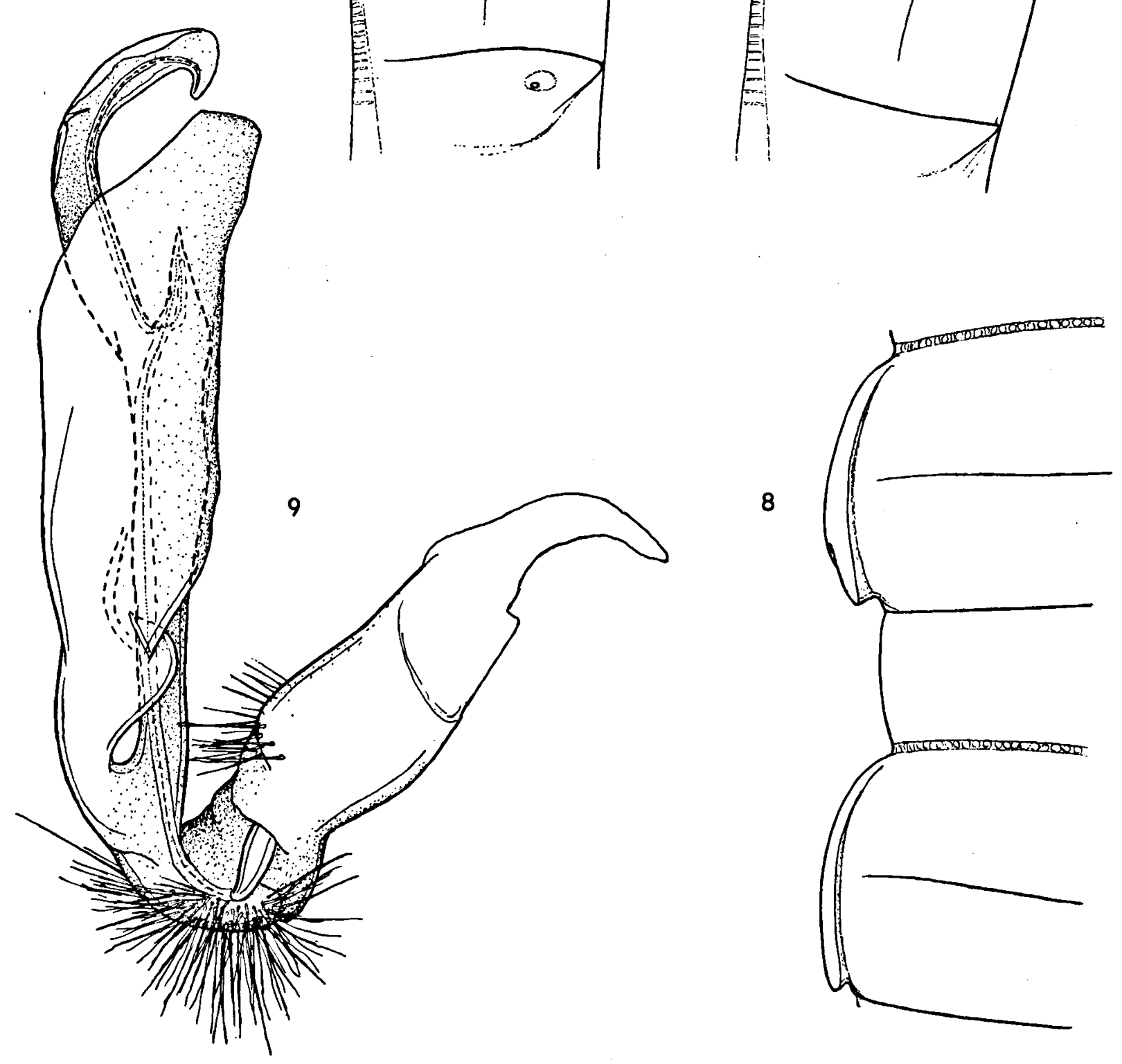

Figs. 7-9. Dicladosomella segmentata nov. gen., nov. spec.: 7 , left side of 10th and 11 th somites of $\delta$ paratype, lateral aspect; 8 , the same, dorsal aspect; 9 , right gonopod of $\delta$ holotype, medial aspect. 
moderate, with rather long setae. Sternite of 4th somite rather wide, widely concave; pubescence moderate, the setae of moderate length. Sternite of 5th somite having between the anterior coxae a process about as wide as the distance between the coxae, a little longer than wide, distally rounded. Anterior side of process widely convex; the process directed ventrad and a little cephalad, projecting slightly in front of the sternite. Apex of process with a rather dense brush of short setae. Posterior side of process widely concave; pubescence longish, sparse. Behind the process a deep transverse furrow. Caudal half of sternite with a deep median impression. Pubescence moderate, setae longish. Sternite of 6 th somite flat, not at all raised above the ventral level of the ring, but with a rather deep transverse furrow. Coxal sockets somewhat raised, a little pressed aside. Setation longish, but sparse. Sternite of 7 th somite with the transverse pregonopodial ridges indistinct. Coxae of ambulatory legs somewhat pressed aside. Sternite of 8 th somite with the anterior coxae a little more widely separated, the sockets weakly raised. Anterior half of sternite flat, scarcely raised, sloping a little cephalad. No transverse furrow. Posterior half of sternite with a wide longitudinal impression. Pubescence weak to moderate, with setae of moderate length. Legs of moderate length, a little longish, moderately stout. Prefemur somewhat incrassate, widely convex dorsally. Femur scarcely arched. Ventral side of all podomeres with a rather dense pubescence of longish setae. Dorsal pubescence apparent only in the distal podomeres, particularly in the tibiae and tarsi. Scopulae present in the anterior legs, thinning out and absent from the legs of the second half of the body. Relative length of podomeres 2 to 6 in middle part of body: $0.65,1.00$, $0.55,0.55,0.70$. First leg with a strong femoral process. Coxae of 2 nd pair not distinctly produced.

Anal somite: Dorsal profile weakly convex. Epiproct of moderate length, rather thick and very broad. Sides concavely and rather weakly converging, becoming almost parellel towards the apex, and finally a little convex (near the apex an indication of a stepwise narrowing). Ventral side of epiproct faintly concave. Apex broadly truncate, widely concave. Setae not on tubercles. Paraprocts with moderately wide and rather low marginal rims. The setae on faint swellings. Hypoproct rather broad, parabolically rounded. Setae not on tubercles.

Gonopods (fig. 9): Coxa short in relation to length of telopodite, slightly crooked distally, with an anterior setiferous area on the projecting part. Prefemur short, ovoid, its longitudinal axis almost transverse on the main axis of the acropodite. Acropodite with a quite short femoral section, deeply split into tibiotarsus and solenomerite. Tibiotarsus arising from the posterior side of the femorite, narrow at base, but soon expanding in a long and rather wide lamina, which conceals most of the solenomerite in medial aspect. Near its base it has a slight medioanterior incision. Solenomerite very long, slender, exceeding the tibiotarsus considerably in length. At about three fifths of its length it has an acuminate triangular process containing a loop of the spermal channel. From there onwards the solenomerite bends rather abruptly in a laterocaudal direction, making an almost semicircular curve, and bearing about halfway a hyaline lappet on its medioposterior side. Spermal channel running along the medial side of the solenomerite.

Female: Head with the clypeus only slightly less impressed towards the labrum. Vertex transversely slightly more convex in the middle, and less laterally. Antennal sockets separated by 1.6 times the diameter of a socket or by 0.8 times the length of the 2 nd antennomere. Relative length of antennomeres 2 to $6: 1.00,0.90,0.90,0.85,0.90$. Collum almost evenly convex transversely. Somites with pleural keels in 2nd to 4th somites more prominent, but absent from the 6th somite onwards. Sternites as long as wide. Cross impressions weakly developed; pubescence moderate. Legs slender, especially prefemur and femur; femur straight. Pubescence a little less dense, but ventrally present on all podomeres. Relative length of podomeres 2 to $6: 0.80,1.00,0.50,0.50,0.75$. Coxa of 2nd legs having a somewhat callous, conical process, pointing laterad and a little caudad, on its caudal side. Epigynal structure consisting of a deep median subrectangular incision of the ventral side of the 3 rd somite, bordered laterally by a somewhat convex lobe. The bridge bordering the caudal side of the incision has a minute medial triangle pointing cephalad. 


\section{REFERENCES}

ATtEms, C., 1931. Die Familie Leptodesmidae und andere Polydesmiden. Zoologica, Stuttg., 30 (3/4): 1-150.

BrölemanN, H. W., 1913. The Myriapoda in the Australian Museum. Part II. - Diplopoda. Rec. Aust. Mus., 10: 77.158, pls. XIV-XVIII.

Chamberlin, R. V., 1920. The Myriopoda of the Australian region. Bull. Mus. comp. Zool. Harv., 64: 1-269.

Jrekel, C. A. W., 1968. On the classification and geographical distribution of the family Paradoxosomatidae (Diplopoda, Polydesmida): i-vii, 1-162 (Ph.D. thesis, University of Amsterdam).

1979. Notes on the classification of some little-known Australian paradoxosomatid genera (Diplopoda, Polydesmida). J. nat. Hist., 13: 649-658.
- 1980. $\Lambda$ new genus and two new species of the family Paradoxosomatidae from Australia (Diplopoda, Polydesmida). Bull. zoöl. Mus. Univ. Amst., 7: 1-10.

—, 1981. Australia Expedition 1980; legit C. A. W. Jeekel and $\mathbf{\Lambda}$. M. Jeekel-Rijvers. List of collecting stations, together with general notes on the distribution of millipedes in eastern Australia and Tasmania. Verslagen technische Gegevens Inst. taxon. Zoöl. (Zoöl. Mus.) Univ. Amsterdam, 30: 1-59.

Verhoeff, K. W., 1928. On Diplopoda in the Australian Museum, Sydney. Rec. Aust. Mus., 16: 79-115, pls. VI-XII.

- 1937 . Ueber einige neue Diplopoden aus Australien. Rec. Aust. Mus., 20: 133-149.

, 1941. Zur Kenntnis australischer Strongylosomiden und einiger anderen Diplopoden. Lunds Univ. Årsskr., (N.F., 2) 36 (17): 1-25. 